\title{
An annotated type catalogue of the turtles (Testudines: Pleurodira: Chelidae) in the collection of the Western Australian Museum.
}

\author{
Ryan J. Ellis ${ }^{1}$ and Arthur Georges ${ }^{2}$ \\ 1 Department of Terrestrial Zoology, Western Australian Museum, 49 Kew St, Welshpool, 6106, \\ Australia. Email: Ryan.Ellis@museum.wa.gov.au \\ 2 Institute for Applied Ecology, University of Canberra, Canberra, 2601, ACT, Australia.
}

\begin{abstract}
An annotated catalogue is provided for the type specimens of turtles (Testudines: Chelidae) in the herpetological collection of the Western Australian Museum. The collection currently holds eight type specimens representing five named taxa from Australia and Timor-Leste, two of which are currently considered as valid at the specific or subspecific level. We also take into consideration the taxonomic status of some species and synonymise Chelodina kuchlingi with C. oblonga and Macrochelodina walloyarrina with C. burrungandjii.
\end{abstract}

KEYWORDS - type specimens, Testudines, Chelidae, Western Australian Museum

\section{INTRODUCTION}

The herpetofaunal collection of the Western Australian Museum (WAM) is one of the largest collections in Australia, containing over 160,000 specimens, representing the long history of the collection and the special interest in this faunal group by current and previous curators and research staff. From the year of the museum's foundation (1891) to 1912, amphibians and reptiles were accessioned in a series of six general registers, the last of which was the Zoological Register 1907-1912 which included all other museum collections and materials obtained, including all terrestrial and aquatic zoology, history, anthropology and archaeology department collections.

In 1912 a separate register was established specifically for herpetological specimens. Specimens accessioned into the herpetological register obtained a number prefixed with ' $R$ '. This prefix is still in use to denote registration numbers and specimens associated with the herpetological collection. Where specimens could be matched to registration numbers, the specimens from the pre-departmental registers were re-reregistered into the new system and given ' $R$ ' numbers. It is unknown if this was completed for the entire collection; however, upon review of historic registers, it seems evident that re-registration of specimens accessed prior to the current herpetology register (pre-1912) was completed in stages by numerous museum staff over a number of years.
Many historic specimens have notations indicating a specimen has been re-registered in the new system along with the date completed, sometimes signed by the person responsible. A large number of early register entries are not accompanied with notations of reregistration and no specimen can be located, indicating specimens were gifted to other institutions, discarded or lost.

Since the first specimen to be accessioned into the herpetological register in 1912 (WAM R1; Moloch horridus, previously registered as 12957 in the original Catalogue of the Museum), the collection has continued to grow steadily, particularly in the past 50 years, during which more than $80 \%$ of the specimens have been accumulated (see How and Cowan 2006). The collection primarily comprises Western Australian species, but does contain significant comparative material from other Australian states and territories and some overseas regions, particularly Indonesia and Timor Leste. The collection includes over 7,850 primary and secondary type specimens.

Testudines are represented by 1,248 specimens within the collection, including whole preserved (fluid and dry), and skeletal (whole skeletons and carapace only) specimens and eggs. The testudine types comprise only ten specimens representing five taxa, of which two are currently considered as valid species or subspecies. Of these ten specimens, one specimens is currently considered lost. The validity of two species 
(Chelodina kuchlingi and Chelodina walloyarrina) is still in question and requires further investigation (see TTWG 2014).

WAM published a list of types annually in the Annual Report from 1960 to 1969 . A total of 10 parts of the type list were presented, of which all but part 1 (1959-60) and part 3 (1961-62) included herpetological type material (Anonymous 1961, 1963, 1964, 1965, 1966, 1967, 1968, 1969). The herpetological lists, compiled by Glen Storr, only presented primary type specimens within the collection (holotypes, syntypes, lectotypes and neotypes). Two chelid type specimens were listed in the 1960-61 annual report, namely Chelodina millymillyensis Glauert, 1923 and Emydura inspectata Glauert, 1954 (Anonymous 1961). Owing to the limited distribution of the annual reports, it is unlikely that these type lists reached their target audience, evident by the designation of a lectotype for C. milly-millyensis by Cogger et al. (1983) despite holotype information being presented, even though incorrectly, in the 19601961 annual report (Anonymous 1961). A decision to discontinue publishing the type list in annual reports was published in the 1969-1970 Annual Report. This was, to be replaced by publication of a consolidated and revised type list, incorporating previous published type information and projected to appear as a WAM special publication (Anonymous 1970). No such publication of type lists or material has occurred for the herpetological collection.

WAM in addition to the Australian National Wildlife Collection (ANWC), Canberra and Tasmanian Museum and Art Gallery (TMAG), Hobart are the only Australian institutions not to have published a comprehensive list of herpetological type material held within their collections. In accordance with Recommendation $72 \mathrm{~F}$ of the Code, we aim to give an account of the herpetofaunal type material held in the collection of WAM. This paper is the first part of a series aimed at listing all type material of amphibians and reptiles held by WAM.

\section{METHODS}

Information on type specimens was obtained from the original description and compared with information retrieved from accession data, jar labels, personal communications and subsequent publications relating to relevant type material. All type specimens in the collection of WAM were examined in addition to any respective label information and notations. This catalogue also includes type specimens of species that have subsequent to their description been synonymised and/or resurrected from synonymy with other taxa. Currently valid names are in accordance with the most recent the Turtle Taxonomic Working Group (TTWG) $7^{\text {th }}$ edition of Turtles of the World checklist (2014), unless otherwise stated. This catalogue was prepared in accordance with the rules and recommendations of the
Code (ICZN 1999). In accordance with the Code, the following 'name-bearing' and 'other' type specimens terminology is used here:

Holotype: single specimen upon which new nominal species-group taxon is based in the original publication (Article 73.1).

Paratype: each specimen of a type series other than the holotype (Article 72.4.5.; Recommendation 73D).

Syntypes: specimens of a type series that collectively constitute the name-bearing type (Article 73.2).

Lectotype: may be designated from the syntypes to become the unique name bearer of the name of a nominal species-group taxon and the standard for its application (Article 74.1).

Paralectotype: following the designation of a lectotype, all remaining syntypes become paralectotypes (Article 74.1.3; Recommendation 74F).

\section{FORMAT}

ORIGINAL BINOMEN

\section{Genus species subspecies Author, year.}

\author{
Referenced figures
}

\section{Original type species citation}

Author, year, title, journal, page(s), [page of description].

\section{Primary type (Holotype/Lectotype/Syntypes)}

Registration number, locality (latitude/longitude), collector(s) and collection date.

\section{Secondary type(s) (Paratypes/Paralectotype)}

Registration number, locality.

\section{Current nomenclature}

Current generic and specific recognition of the species, if different from original description.

\section{Current status}

Current status and validity of the species, synonymies, if different from original description.

\section{Remarks}

Additional information provided on subjects including the history and status of types, location of additional type specimens and information regarding the synonymy or resurrection of a species or subspecies if necessary and available. 
Each taxon is presented by the name provided by the original author(s), followed by the author's name, and year of publication. Species names are given in the exact format in which they were first published, some of which do not correspond with the current provisions of the ICZN Code for Zoological Nomenclature (1999). The original type species publication citation follows next displaying the author(s), year, title (of article or book), journal (unless otherwise), page(s) and the page the description of the species commences in square brackets $([x])$. Primary type (holotype or lectotype) information includes the WAM registration number, locality, latitude and longitude (in degrees minutes seconds) as presented in the description, collector(s) name and collection date. Type localities shown in quotes are those derived from the original published descriptions and are presented exactly as presented in original descriptions. Where latitude and longitude were not provided in the original description, location was obtained from accession data or subsequent designation by WAM staff, presented in square brackets $([\mathrm{x}])$. All dates are presented as day, month, year, or month, year or year where information is not provided in the original description or relevant information sources. On the next line secondary types (paratypes, paralectotypes and syntypes) are displayed showing WAM registration number and locality. Specific locality (latitude and longitude) and collection details (collector and date) are not provided for non-name-bearing type specimens. Specimens marked with an asterix (*) indicate specimen no longer held in the collection of WAM, either due to gifting or loan to other institutions or loss of specimen. Details of specimens no longer held in the collection are discussed further in the Remarks section of each species where information was available.

Current nomenclature and status are only presented where change from the original binomen or trinomen has occurred such as generic changes, specific amendments, changes to species or subspecies status and synonymy or resurrection from synonymy. Remarks include relevant information on issues and errors from original description, specimens, historical remarks or subsequent publications referring to the species or specimens as well as information relating to the synonymy or resurrection of the species or information pertaining to lost or destroyed specimens. Square brackets $([\mathrm{x}])$ indicate corrections or additions of information presented in the original description or subsequent publications. The prefix $\mathrm{R}$ is used to denote that the registration number corresponds with the herpetofaunal collection of WAM.

\section{ACCOUNT OF TYPE SPECIMENS}

\author{
Family Chelidae
}

Chelodina kuchlingi Cann, 1997

Figure 1

Cann, J. (1997). Kuchling's long-necked turtle. Monitor 9(1): 41-44 [41]

\section{Holotype}

R29411, 'Kalumburu', Western Australia [14²18'S, $126^{\circ} 38^{\prime} \mathrm{E}$ ], presented by W.H. Butler in 1966 (Figure 1).

\section{Current status}

Junior synonym of Chelodina oblonga (Gray, 1841), synonymy of this paper.

\section{Remarks}

Also described in the book Australian Freshwater Turtles by Cann (1998), where it states 'Chelodina kuchlingi sp. nov.' and 'A new species of long-necked turtle is described here, from the Kimberley region of north-west Australia' (p. 97) implying the description of a new species, in error. The description appearing in the 1998 publication does not differ from the text or images of the original 1997 publication other than a few minor edits and inclusion of acknowledgements. Cann originally intended for the formal description of the species to appear in the book; however, due to printing delays while the book was in press the description was published in Monitor to prevent the new taxa being described by others who were aware of it (G. Shea, pers. comm.). The validity of the species was questioned following preliminary morphological analysis by Georges and Thomson (2006) based on the species description from a single specimen of uncertain origin; however, it was not formally listed as a junior synonym of Chelodina rugosa (now C. oblonga, see ICZN 2013) until a later publication (Georges and Thomson 2010), a synonymy supported by TTWG (2010). The species was raised from synonymy of C. rugosa by TTWG (2014) based on additional unpublished information provided by $\mathrm{G}$. Kuchling who challenged the status of the species as a synonym of C. oblonga, see TTWG (2014).

Damage to and condition of the holotype specimen described by Cann (1997) is consistent with a captive containment, having a worn plastron and very worn down or cut nails. The locality and other information for the holotype specimen are possibly in error. Cann (1997) detailed 'H. Butler' as the collector and 'Kalumburu, Western Australia' as the locality; however, the origin of the specimen is unknown. The holotype was given to $\mathrm{H}$. Butler by another person who collected and held it in captivity for an unknown length of time before it was given to the University of Western Australia where it 
was held for a short period before donation to WAM (S. Thomson, pers. comm.). Specimen accession registration states the collection date as 'x-xii-1965-i-i-1966' with accession date '30:viii:67'.

The validity of the species is still in question and requires further investigation; see TTWG (2014). Until further supporting evidence for the species to be recognised as a distinct taxon is published, we maintain it as a junior synonym of Chelodina oblonga following Georges and Thomson (2010). The species was described from a single specimen of questionable origin. The species morphology is consistent with C. oblonga and, in the lack of supporting evidence for recognition as a valid taxonomic unit and for the resurrection from synonymy by the TTWG (2014), the species is considered a junior synonym. Molecular analysis and morphological examination of additional specimens are likely to resolve the taxonomic status of the species. Molecular and morphological data provide evidence of only two Chelodina lineages occurring in the Kimberley, representing $C$. burrungandjii and $C$. oblonga (Georges et al. 2002; Georges and Thomson 2006; 2010; Georges and Merrin 2008).

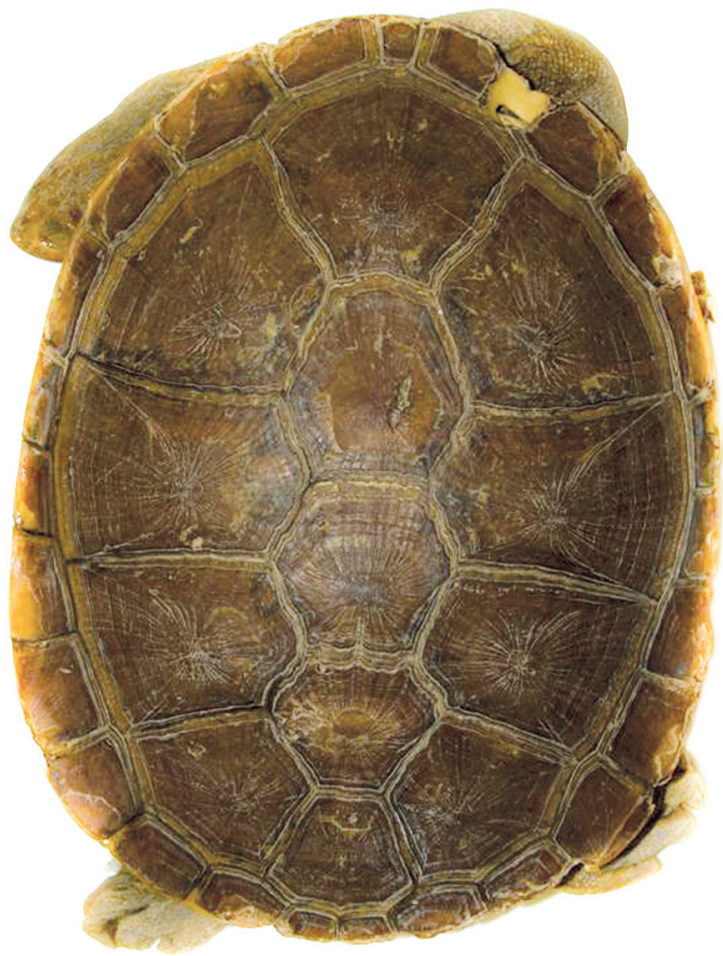

\section{Chelodina mccordi timorlestensis Kuchling, Rhodin, Ibarrondo \& Trainor, 2007}

Figure 2

Kuchling, G., Rhodin, A.G.J., Ibarrondo, B.R. and Trainor, C.R. (2007). A new subspecies of the snakeneck turtle Chelodina mccordi from TimorLeste (East Timor) (Testudines: Chelidae). Chelonian Conservation and Biology 6(2): 213-222 [213].

\section{Holotype}

R165888, 'area of Lake Iralalaro, Timor-Leste' [08³1'26"S, 126 59'50"E], collected by A.B.F. Ly and donated to G. Kuchling 23 May 2006, presented to WAM by G. Kuchling (Figure 2).

\section{Current status}

Junior synonym of $C$. mccordi timorensis (formerly $C$. timorensis McCord, Joseph-Ouni and Hagen, 2007), fide Rhodin et al. (2008) and TTWG (2014).

\section{Remarks}

The species Chelodina timorensis McCord et al., 2007 was described in the hobbyist periodical Reptilia only months prior to the description of $C$. mccordi

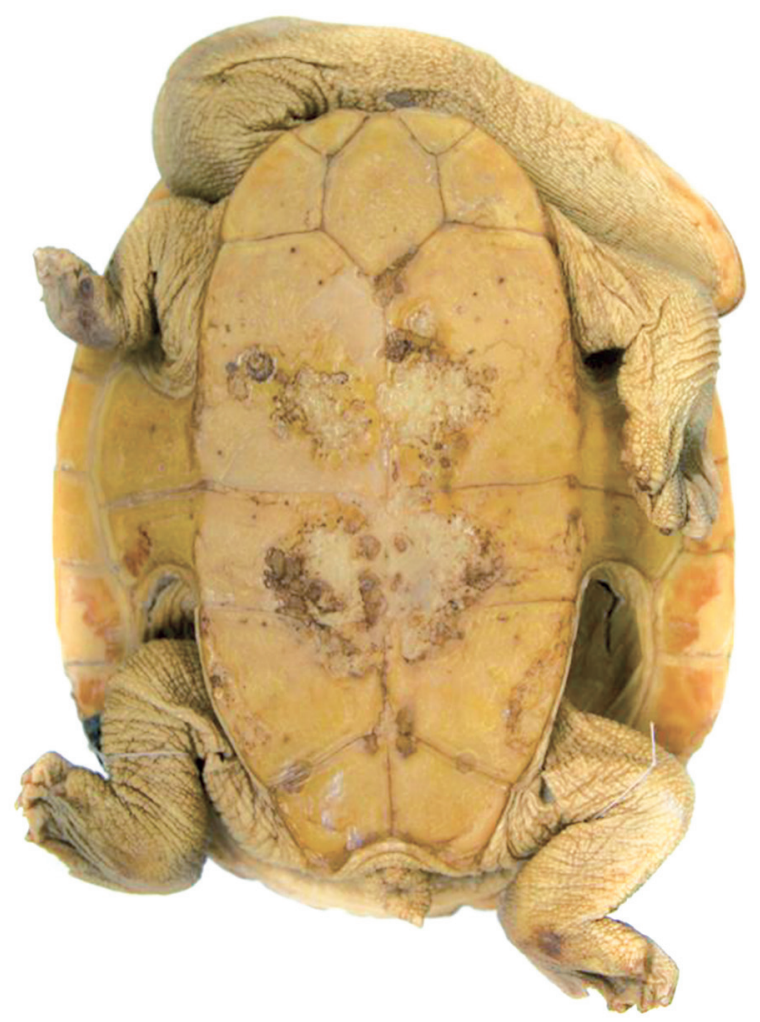



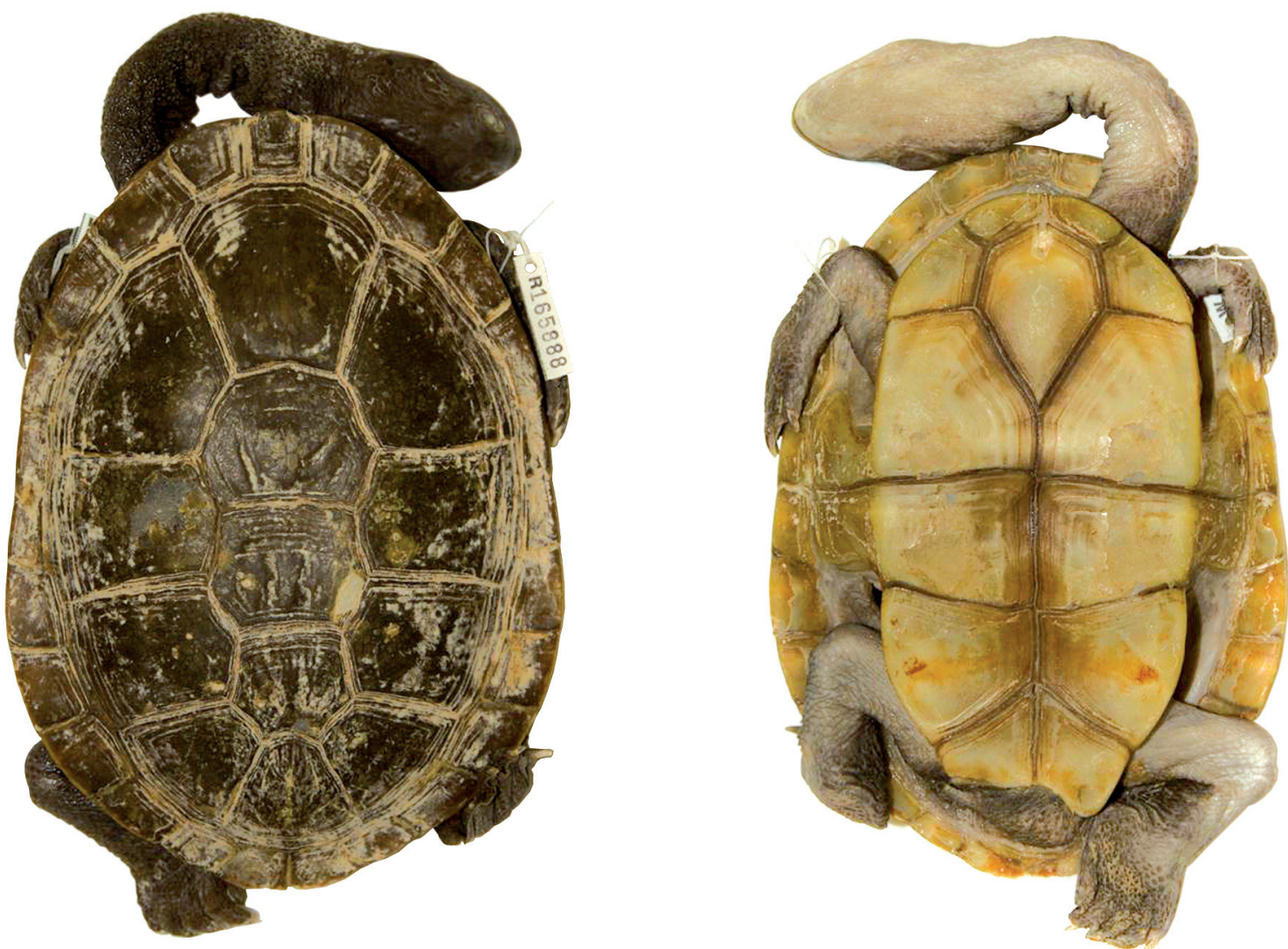

FIGURE 2 Chelodina mccordi timorlestensis, holotype (R165888).
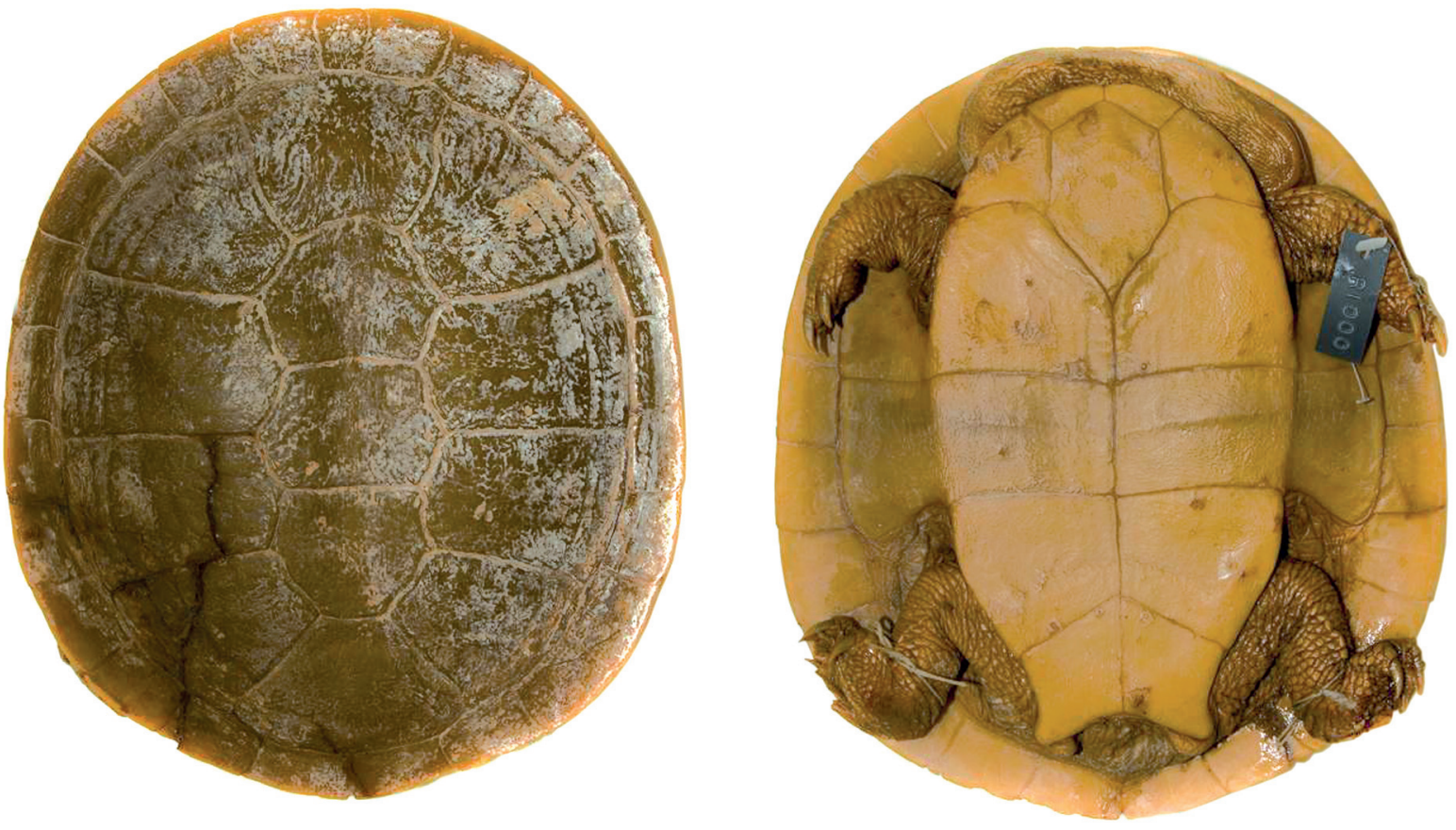
timorlestensis, see notes added in proof in Kuchling et al. (2007) and Rhodin et al. (2008). The latter description by Kuchling et al. (2007) identified the taxon as a subspecies, therefore by inference reducing the species described by McCord et al. (2007) to subspecific status; see also Georges and Thomson (2010).

\section{Chelodina milly-millyensis Glauert, 1923}

Figure 3

Glauert, L. (1923). Contributions to the Fauna of Western Australia No. 2. A new freshwater tortoise from the Murchison River. Journal of the Royal Society of Western Australia 9: 53-56 [53].

\section{Lectotype}

R1000, 'Milly Milly Station, Murchison River', Western Australia [26 $\left.05^{\circ} \mathrm{S}, 116^{\circ} 41^{\prime} \mathrm{E}\right]$, collected by J.E. Scully, accessed 19 October 1922, designated by H.G. Cogger (Cogger et al. 1983) (Figure 3).

\section{Paralectotypes}

R911, R912, R1106*, Milly Milly Station, Western Australia.

\section{Current status}

Junior synonym of Chelodina steindachneri (Siebenrock, 1914), fide Cogger et al. (1983) and supported by TTWG (2014).

\section{Remarks}

Glauert described the species based on four available specimens; however, a holotype was not formally designated. R1000 was described in detail in the original description due to its larger size and better condition relative to other specimens. In the type list presented in the WAM 1960-1961 annual report, the specimen R1000 was listed as a holotype (Anonymous, 1961); however, this is in error. As Glauert presented registration numbers for four specimens but did not nominate a holotype, all specimens are considered syntypes. The nomination of R1000 as a holotype in the annual report was in error and should have been listed as a lectotype or all four specimens presented as syntypes. Due to the limited circulation of annual reports the identification of this specimen as holotype remained unnoticed. Cogger et al. (1983) correctly designated R1000 as the lectotype of the four syntypes resulting in the remaining three specimens becoming paralectotypes. Of the four type specimens, the lectotype (R1000) and one paralectotype (R1106) are whole wet specimens. The remaining paralectotypes (R911 and R912) are carapace only specimens. Paralectotype R1106 could not be located within the WAM collection during the chelid type specimen audit for this paper and subsequent searches. The specimen was not recorded in previous audits in 1999 and 2008-2010 that included chelid specimens and is presumed lost.

\section{Emydura inspectata Glauert, 1954}

Figure 4

Glauert, L. (1954). Herpetological miscellanea IV. - A new swamp tortoise from the Swan River district. Western Australian Naturalist 4(6): 125-127 [125].

\section{Holotype}

R11092, 'Warbrook, about 24 miles $\mathrm{N}$ of Perth', Western Australia [31 $\left.43^{\prime} 15^{\prime \prime S}, 116^{\circ} 00^{\prime} 55^{\prime \prime E}\right]$, collected by A. Gates in July 1953 (Figure 4).

\section{Paratype}

R11093*, Warbrook, Perth, Western Australia.

\section{Current status}

Junior synonym of Pseudemydura umbrina (Siebenrock, 1901), fide Williams (1958), supported for synonymy by Cogger et al. (1983) and TTWG (2014).

\section{Remarks}

In the description, Glauert refers to R11092 as 'the type' while R11093 is referred to as 'the second specimen'. The type specimens were presented to the museum on 27 April 1954 by R. Boyd after they were kept in captivity for nine months following their collection by A. Gates in 1953 .

The paratype specimen (R11093) was loaned to the late J.M. Legler, visiting professor at the University of New England, New South Wales on 27 June 1974 with four additional $P$. umbrina specimens. The specimens were taken back to Utah, United States where they were held in Legler's private collection at the University of Utah. The specimen loan form states 'Permission granted to study in USA and to skeletonize one of the females listed, per. Telephone conversation between J.M. Legler and G. Storr 11 July 1974'; however, it is unknown if R11093 was the specimen selected to be skeletonized, Glauert did not state the sex of the specimen in the original description. All specimens are now held at the Natural History Museum of Utah, Utah, United States (NHMU) following Legler's death in March 2014. The paratype and other specimens loaned in addition to Australian specimens collected by and held in Legler's private collection are currently awaiting return to respective institutions of the states from which specimens were loaned or collected. The current condition and status of the specimen is not known. 

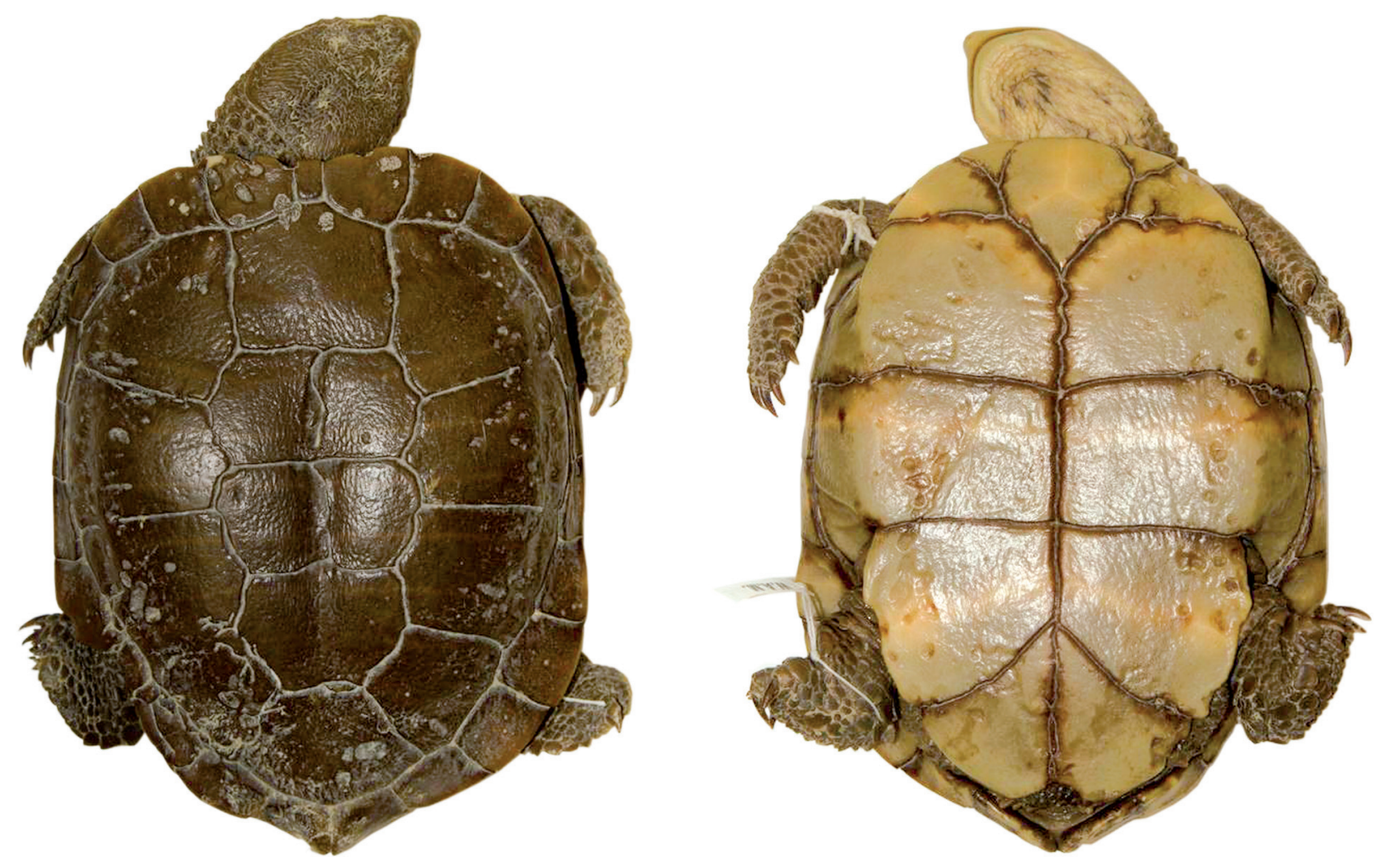

FIGURE 4 Emydura inspectata, holotype (R11092).
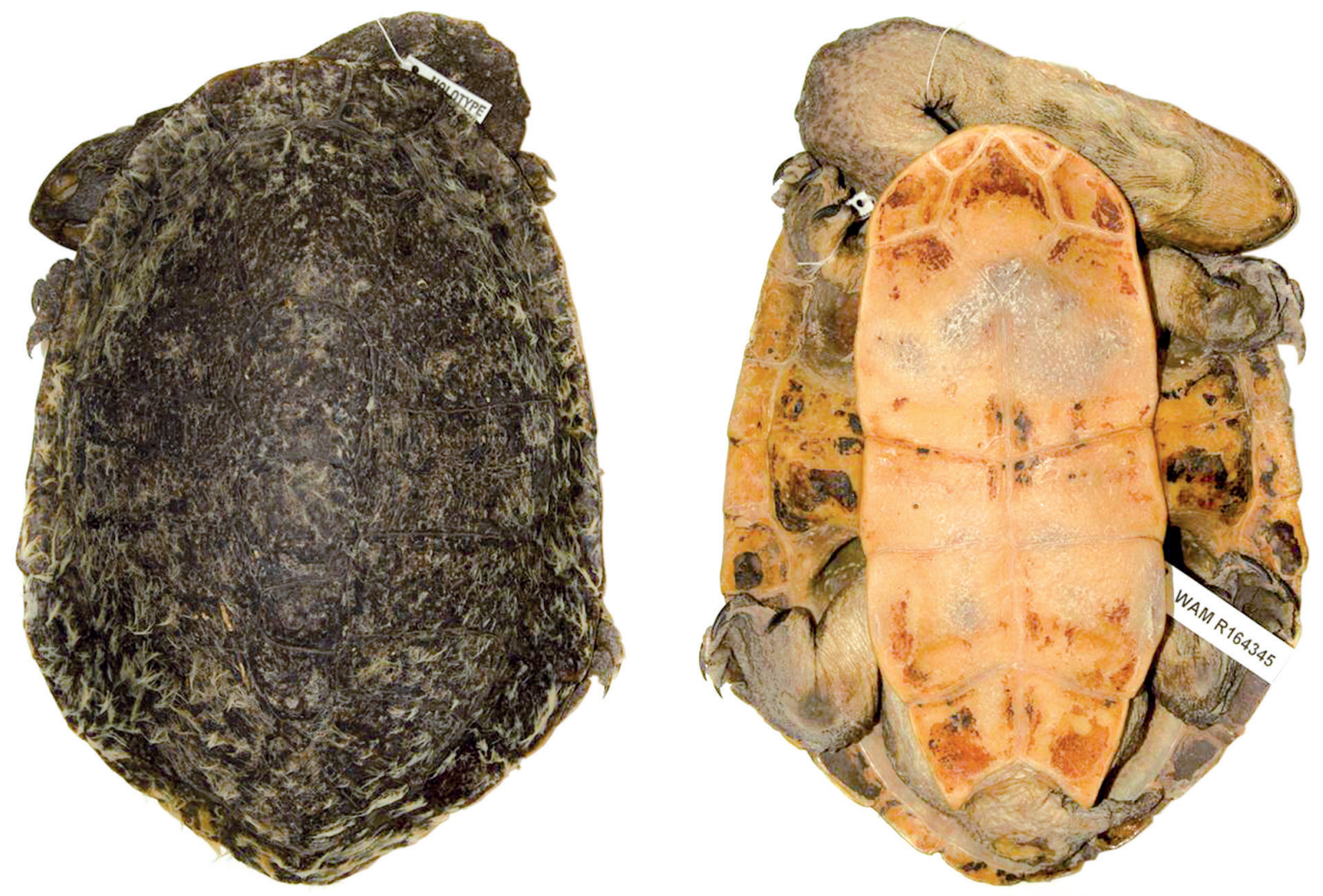

FIGURE 5 Macrochelodina walloyarrina, holotype (R164345). 


\section{Macrochelodina walloyarrina McCord \& Ouni, 2007}

Figure 5

McCord, W.P. and Ouni, M.J. (2007). A new genus of Australian longneck turtle (Testudines: Chelidae) and a new species of Macrochelodina from the Kimberley region of Western Australia (Australia). Reptilia 31: $56-64[59]$.

\section{Holotype}

R164345, 'Fitzroy River Crossing, Fitzroy River', Western Australia [18 $\left.10^{\prime} 50^{\prime \prime} \mathrm{S}, 125^{\circ} 35^{\prime} 50^{\prime \prime} \mathrm{E}\right]$, collected by D. Wedd, G. Erikson, J. Cover and J. Seyjagat on 20 July 2004 (Figure 5).

\section{Paratype}

R164346, Carson River, Western Australia.

\section{Current status}

Junior synonym of Chelodina burrungandjii Thompson, Kennett and Georges, 2000, synonymy of this paper.

\section{Remarks}

Listed as a junior synonym of Chelodina burrungandjii by Georges and Thomson (2010) based on a lack of evidence to support the specific recognition, further complicated by issues of hybridisation and introgression between C. burrungandjii and C. rugosa (now C. oblonga, see ICZN 2013) in the Kimberley region (see Georges and Thomson 2010). TTWG noted the synonymy by Georges and Thompson but chose to resurrect the species stating 'we provisionally retain walloyarrina as distinct [species] until published molecular data resolves the issue' (TTWG 2010, p 000.141). The validity of the species is still in question and requires further investigation (see TTWG, 2014). In the lack of supporting evidence for the resurrection of the species from synonymy with $C$. burrungandjii by TTWG (2014) we follow Georges and Thomson (2010) and consider the species a junior synonym of $C$. burrungandjii, noting no subsequent work has identified any supporting evidence for the species. Molecular and morphological data show evidence for only two Chelodina lineages in the Kimberley region, representing $C$. burrungandjii and $C$. oblonga (Georges et al. 2002; Georges and Thomson 2006; 2010; Georges and Merrin 2008). Further molecular analysis and morphological examination of additional specimens are likely to resolve the taxonomic status of the species.

Of the type specimens, the holotype (R164345) is an entire wet specimen while the paratype (R164346) is a carapace and skeleton only. Six eggs belonging to the paratype specimen are registered separately as R150324. The holotype was one of six individuals collected north of Fitzroy Crossing on the Fitzroy River during a collecting expedition by members of the National Aquarium (Baltimore, USA) and Territory Wildlife Park (Darwin, NT) in July 2004. It was freighted to the US and was housed at the National Aquarium where it subsequently died on 8 May 2004, eight days after arriving (J. Seyjagat, pers. comm). Death was attributed to aggression from other enclosure inhabitants.

The specimen was then made available to McCord for use in the species description with the support of additional specimens from Australia. The WAM paratype was imported into the US by McCord through the University of Canberra to aid the description. In the description the paratype was described as skeletonized, although at the time of publication the specimen was frozen. It was subsequently skeletonised at the American Museum of Natural History (AMNH) as its poor condition made it unsuitable for whole preservation in liquid. All specimens were sent to the AMNH in 2009 for preparation and preservation before being returned to Australia and deposited at WAM in 2009 in accordance with conditions of the permit issued to the collectors of the specimens. Western Australian Department of Parks and Wildlife (DPaW; formerly Dept. Environment and Conservation, DEC; Dept. Conservation and Land Management, CALM) collecting permits, Regulation 17 license to take fauna for scientific purposes conditions state 'All holotypes and syntypes and a half share of paratypes of species or subspecies permitted to be permanently taken under this license shall be donated to the Western Australian Museum'. Three additional paratypes are held in the Australian Museum (AM) (R136058, R136063, R136150) and a single specimen in the AMNH (AMNH R159947).

\section{ACKNOWLEDGEMENTS}

The authors are grateful to Paul Doughty (WAM), Aaron Bauer (Villanova University) and Glenn Shea (University of Sydney and Australian Museum) for technical discussions and comments on earlier drafts of the catalogue, John Seyjagat (National Aquarium, Baltimore), William McCord (East Fishkill Animal Hospital, New York) and Scott Thomson (Museum of Zoology, University of São Paulo) for providing additional information on the history of C. walloyarrina type specimens, Don Bradshaw (University of Western Australia) and Scott Thompson for information on the holotype of C. kuchlingi. Earlier versions of the manuscript were greatly improved by two reviewers, A. Bauer and G. Shea who provided useful comments and suggestions for improvement. 


\section{REFERENCES}

Anonymous. (1961). Type specimens in the Western Australian Museum (Part 2). Western Australian Museum Annual Report 1960-61: 35-39.

Anonymous. (1963). Type specimens in the Western Australian Museum (Part 4). Western Australian Museum Annual Report 1962-63: 38-40.

Anonymous. (1964). Type specimens in the Western Australian Museum (Part 5). Western Australian Museum Annual Report 1963-64: 38-40.

Anonymous. (1965). Type specimens in the Western Australian Museum (Part 6). Western Australian Museum Annual Report 1964-65: 46-48.

Anonymous. (1966). Type specimens of the Western Australian Museum (Part 7). Western Australian Museum Annual Report 1965-66: 38-42.

Anonymous. (1967). Type specimens of the Western Australian Museum (Part 8). Western Australian Museum Annual Report 1966-67: 59-60.

Anonymous. (1968). Type specimens of the Western Australian Museum (Part 9). Western Australian Museum Annual Report 1967-68: 62-64.

Anonymous. (1969). Type specimens of the Western Australian Museum (Part 10). Western Australian Museum Annual Report 1968-69: 58-60.

Anonymous. (1970). Type specimens in the Western Australian Museum (discontinued in the Annual Report). Western Australian Museum Annual Report 1969-70: 44.

Cann, J. (1997). Kuchling's Long-neck Turtle. Monitor Journal of the Victorian Herpetological Society 9: 41-44.

Cann, J. (1998). Australian Freshwater Turtles. Beaumont Publishing, Singapore.

Cogger, H. G. (2014). Reptiles and Amphibians of Australia. CSIRO Publishing, Collingwood, Victoria. 1033 pp.

Cogger, H. G., Cameron, E. E. and Cogger, H. M. (1983). Zoological Catalogue of Australia. Vol. 1. Amphibia and Reptilia. Australian Government Publishing Service, Canberra, ACT. 313 pp.

Georges, A., Adams, M. and McCord, W. (2002). Electrophoretic delineation of species boundaries within the genus Chelodina (Testudines: Chelidae) of Australia, New Guinea and Indonesia. Zoological Journal of the Linnean Society 134: 401-421.

Georges, A. and Merrin, L. (2008). Freshwater turtles of tropical Australia: Compilation of distributional data. Report to the CERF Tropical Rivers and Coastal Knowledge (TRACK) Project, Charles Darwin University. University of Canberra, ACT. 18 pp.

Georges, A. and Thomson, S. (2006). Evolution and Zoogeography of Australian Freshwater Turtles. In: Merrick, J. R., Archer, M., Hickey, G. M. and Lee, M. S. Y. (eds) Evolution and Biogeography of Australian Vertebrates. Auscipub Pty Ltd, Sydney, pp. 291-308.

Georges, A. and Thomson, S. (2010). Diversity of Australian freshwater turtles, with an annotated synonomy and keys to species. Zootaxa 2496: 1-37.

Glauert, L. (1923). Contributions to the fauna of Western Australia No. 2. A new freshwater tortoise from the Murchison River. Journal of the Royal Society of Western Australia 9: 53-56.
Glauert, L. (1954). Herpetological Moscellanea IV. - A new swamp tortoise from the Swan River district. Western Australian Naturalist 4: 125-127.

How, R.A., and Cowan, M.A. (2006). Collections in space and time: geographical patterning of native frogs, mammals and reptiles through a continental gradient. Pacific Conservation Biology 12: 111-131.

International Commission on Zoological Nomenclature [ICZN]. (1999). International Code of Zoological Nomenclature. Fourth Edition [online] Available at: http:// www.nhm.ac.uk/hosted-sites/iczn/code/ [Accessed 8 Oct. 2014].

International Commission on Zoological Nomenclature [ICZN]. (2013). Opinion 2315 (Case 3351). Chelodina rugosa Ogilby, 1980 (currently Macrochelodina rugosa; Reptilia, Testudines): precedence not granted over Chelodina oblonga Gray, 1841. Bulletin of Zoological Nomenclature 70: 57-60.

Kuchling, G., Rhodin, A. G. J., Ibarrondo, B. R. and Trainor, C. R. (2007). A new subspecies of the snakeneck turtle Chelodina mccordi from Timor-Leste (East Timor) (Testudines: Chelidae). Chelonian Conservation and Biology 6: 213-222.

McCord, W. P., Joseph-Ouni, M. and Hagen, C. (2007). A new species of Chelodina (Testudines: Chelidae) from Eastern Timor Island (East Timor). Reptilia 52: 53-57.

McCord, W. P. and Ouni, M. J. (2007). A new genus of Australian longneck turtle (Testudines: Chelidae) and a new species of Macrochelodina from the Kimberley region of Western Australia (Australia). Reptilia 31: $56-64$.

Rhodin, A. G. J., Ibarrondo, B. R. and Kuchling, G. (2008). Chelodina mccordi Rhodin 1994 - Roti Island snakenecked turtle, McCord's snake-necked turtle, KurraKurra Rote. Conservation Biology of Freshwater Turtle and Tortoises: A Compilation Project of the IUCN/ SSC Tortoise and Freshwater Turtle Specialist Group. Chelonian Research Monographs 5(1): 008.001-008.008.

Siebenrock, F. (1914). Eine neue Chelodina Art aus Westaustralien. Anzeiger der Akademie der Wissenschaften in Wien 17: 386-387.

Thomson, S., Kennett, R. and Georges, A. (2000). A new species of long-necked turtle (Testudines: Chelidae) from the Arnhem Land Plateau, Northern Territory, Australia. Chelonian Conservation and Biology 3: 675-685.

Turtle Taxonomy Working Group [TTWG], [Rhodin, A. G. J., van Dijk, P. P., Iverson, J. B. and Shaffer H.B.]. (2010). Turtles of the World, 2010 update: Annotated checklist of taxonomy, synonomy, distribution and conservation status. Chelonian Research Monographs 5(3): 000.085000.164 .

Turtle Taxonomy Working Group [TTWG], [van Dijk, P. P., Iverson, J. B., Rhodin, A. G. J., Shaffer, H. B. and Bour R.]. (2014). Turtles of the World, 7th Edition: Annotated checklist of taxonomy, synonomy, distribution with maps, and conservation status. Chelonian Research Monographs 5(7): 000.392-000.479.

Williams, E.E. (1958). Rediscovery of the Australian chelid genus Pseudmydura Siebenrock (Chelidae, Testudines). Breviora 84: 1-8 + pl. 1-4.

MANUSCRIPT RECEIVED 8 MAY 2015; ACCEPTED 12 JUNE 2015 